\title{
Effect of Heat Treatment on the Bending Strength and Hardness of Wood*1
}

\author{
Kyung-Rok Won*2, Tae-Hong Kim*2, Kyo-Kil Hwang*2, Song-Ho Chong*3, \\ Nam-Euy Hong*2, and Hee-Seop Byeon*4†
}

\begin{abstract}
Heat treatment improves dimensional stability and sound absorption properties of wood. However, mechanical properties of wood can be deteriorated during the heat treatment. The effect of heat treatment on the bending strength and hardness of wood for Korean paulownia, Pinus densiflora, Lidiodendron tulipifera and Betula costata were measured. The heat treatment temperature has been investigated at $175^{\circ} \mathrm{C}$ and $200^{\circ} \mathrm{C}$, respectively. The results showed that the weight and density of wood decreased after heat treatment. It was found that the density by heat treatment was lower at $200^{\circ} \mathrm{C}$ than that at $175^{\circ} \mathrm{C}$. And, MOE increased with the reduced density. On the contrary, MOR and hardness decreased. In all conditions, It was found that there was a high correlation of $1 \%$ level between bending modulus of elasticity and modulus of rupture.
\end{abstract}

Keywords : heat treatment, density, bending MOE and MOR, hardness

\section{INTRODUCTION}

The demand of wood has risen sharply because of the necessity for environment friendly fuels with an increase of personal income and economic growth. Until recently, Korea is importing more than $90 \%$ of the annual wood consumption $\left(2.60\right.$ million $\mathrm{m}^{3}$ ) because most of the resources are low-diameter wood or low-quality wood in Korea. It is an inevitable consequence because the timber resources of high quality are reducing and every consumer want to use cheap wood resource of high quality.
Recently, the "ThermoWood" (heat treated wood product) is manufactured to make high value and to accept consumers' preference in Europe. And the thermal treatment of wood is an alternative to the chemical treatment for preservation purposes (Poncsak et al., 2006). Also, It has been continuously researching around the world about removing resin from conifer, changing of the material quality for softwood and hardwood, and improving of dimensional stability (Shin et al., 2009). And relatively mild thermal treatments of wood according to a two step process which leads to improved dimensional

*1 Received on June 26, 2012; accepted on September 11, 2012

*2 College of Agriculture \& Life Science, Gyeongsang National University, Jinju 660-701, Korea

*3 Forest Training Institute, Korea Forest Service, Namyangju city, Kyounggido 472-865, Korea

*4 College of Agriculture \& Life Science, IALS. Gyeongsang National University, Jinju 660-701, Korea

${ }^{\dagger}$ Corresponding author : Hee-Seop Byeon (e-mail: hsbyeon@gnu.ac.kr) 
stability (Tjeerdsma et al., 1998). Hydrothermal processing of lignocellulosic materials (wood or agricultural residues) causes a variety of effects including extractive removal, hemicellulose hydrolysis and alteration of the properties of both cellulose and lignin (Garrote et al., 1999). Changes in the chemical structure of wood caused by thermal treatment and modification during heat treatment could be explained by a modification of conformational arrangement of wood biopolymers due to loss of residual water or more probably to plasticization of lignin (Sivonen et al., 2002, Hakkou et al., 2005). And decrease in hydroxyl groups increases the hydrophobicity of wood and reduces the adoption of water (Kamdem et al., 2002, Stamm et al., 1946, Pavlo et al., 2003). The wood structure changes due to decomposition of hemicelluloses, ramification of lignin, and crystallization of cellulose. These changes improve the dimensional stability of wood, increase its resistance to micro-organisms, darken its color, and modify its hardness (Kocaefe et al., 2008). The heat-treated wood is more dimensionally stable in the change of moisture condition and the mechanical properties of heat-treated wood showed relatively higher performance (Kim et al., 2009).

It has been suggested that this study takes a subsequent investigation for the research of the sound absorption property of heat-treated wood at a low temperature and vacuum conditions (Byeon et al., 2010). In this study, the effect of heat treatment on the bending strength and hardness of Korean paulownia, Pinus densiflora, Lidiodendron tulipifera and Betula costata was investigated under different conditions.

\section{MATERIALS and METHODS}

\subsection{Material}

The species of Korean paulownia, Pinus den- siflora, Lidiodendron tulipifera and Betula costata were used in the dry ingredients. Specimens of each species were made from edge grain $20(\mathrm{R}) \times 10(\mathrm{~T}) \times 100 \mathrm{~mm}(\mathrm{~L})$ and flat grain $10(\mathrm{R}) \times 20(\mathrm{~T}) \times 100 \mathrm{~mm}(\mathrm{~L})$ and processed 8 each.

The humidification of specimens was treated over 1 week in the constant temperature and humidity room $\left(20^{\circ} \mathrm{C} \pm 1^{\circ} \mathrm{C}, 65 \% \pm 5 \%\right)$, and heated for 6 hours at $120^{\circ} \mathrm{C}$ in dry oven. The heat treatment of specimens treated at the heating rate $10^{\circ} \mathrm{C} / \mathrm{min}$ heating conditions in the vacuum sintering furnace (KOVACO KSF-100 Type). At this time, maintained for 30 minutes in the maximum temperature of $175^{\circ} \mathrm{C}$ and $200^{\circ} \mathrm{C}$. After heat treatment, the humidification of treated samples were treated again over 1 week in the constant temperature and humidity room $\left(20 \pm 1{ }^{\circ} \mathrm{C}, 65 \pm 2 \%\right)$. After that, bending strength and hardness test of specimen was conducted.

\subsection{Weight and Density Changes}

Weight and density were measured before and after heat treatment of each specimen with electronic scale, and used electronic calipers to measure the size.

\subsection{Bending Strength and Hardness Test}

Bending strength test was conducted using a span $(80 \mathrm{~mm})$ by central method of three points, and carried out test load speed of $1 \mathrm{~mm} / \mathrm{min}$. In this condition, bending MOE and MOR was determined. TAESIN Precision Machinery TSU-2 Universal Mechanical Testing Machine was used for the measurement.

Hardness test was conducted using the universal strength tester by Brinell hardness test method. When the load in the $0.32 \mathrm{~mm}$ indentation hardness was measured using steel balls of $10 \mathrm{~mm}$ diameter by loading rate of $0.5 \mathrm{~mm} / \mathrm{min}$. 
Effect of Heat Treatment on the Bending Strength and Hardness of Wood

Table 1. Mass and density properties of heat-treated woods

\begin{tabular}{|c|c|c|c|c|c|c|}
\hline \multirow{2}{*}{ Species } & \multirow{2}{*}{$\begin{array}{l}\text { Heat treatment } \\
\text { condition }\end{array}$} & & \multicolumn{2}{|c|}{ Mass } & \multicolumn{2}{|c|}{ Density } \\
\hline & & & (g) & $\mathrm{R}_{\mathrm{M}}(\%)$ & $\left(\mathrm{g} / \mathrm{cm}^{3}\right)$ & $\mathrm{R} \rho \quad(\%)$ \\
\hline \multirow{6}{*}{$\begin{array}{c}\text { Korean } \\
\text { Paulownia }\end{array}$} & solid & Mean & 5.730 & 0 & 0.299 & 0 \\
\hline & & S.D & 0.483 & & 0.023 & \\
\hline & 175 & Mean & 4.310 & -24.78 & 0.224 & -25.08 \\
\hline & & S.D & 0.280 & & 0.013 & \\
\hline & 200 & Mean & 3.705 & -35.34 & 0.194 & -35.12 \\
\hline & & S.D & 0.275 & & 0.011 & \\
\hline \multirow{6}{*}{$\begin{array}{c}\text { Pinus } \\
\text { densiflora }\end{array}$} & solid & Mean & 10.960 & 0 & 0.546 & 0 \\
\hline & & S.D & 0.695 & & 0.034 & \\
\hline & 175 & Mean & 9.40 & -14.23 & 0.497 & -9.64 \\
\hline & & S.D & 0.40 & & 0.021 & \\
\hline & 200 & Mean & 8.053 & -26.52 & 0.452 & -17.82 \\
\hline & & S.D & 0.462 & & 0.031 & \\
\hline \multirow{6}{*}{$\begin{array}{l}\text { Lidiodend-ron } \\
\text { tulipifera }\end{array}$} & solid & Mean & 10.550 & 0 & 0.548 & 0 \\
\hline & & S.D & 0.653 & & 0.039 & \\
\hline & 175 & Mean & 7.729 & -26.73 & 0.440 & -20.00 \\
\hline & & S.D & 0.357 & & 0.023 & \\
\hline & 200 & Mean & 6.331 & -39.99 & 0.374 & -32.00 \\
\hline & & S.D & 0.586 & & 0.045 & \\
\hline \multirow{6}{*}{ Betula costata } & solid & Mean & 13.440 & 0 & 0.694 & 0 \\
\hline & & S.D & 0.275 & & 0.023 & \\
\hline & 175 & Mean & 11.755 & -12.53 & 0.648 & -6.67 \\
\hline & & S.D & 0.774 & & 0.037 & \\
\hline & 200 & Mean & 9.174 & -31.74 & 0.572 & -11.01 \\
\hline & & S.D & 0.371 & & 0.021 & \\
\hline
\end{tabular}

Notes; $\mathrm{R}_{\mathrm{M}}$ : Ratio change in mass after heat treatment,

$\rho$ : Density,

$\mathrm{R}_{\rho}$ : Ratio change in density after heat treatment,

S.D: Standard deviation.

\section{RESULTS and DISCUSSION}

\subsection{The Weight and Density of Species According to the Heat Treatment}

Table 1 shows weight of each species after heat treatment. The weight of wood after heat treatment decreased according to increase of temperature. Especially, Korean paulownia and Lidiodendron tulipifera showed very high decreasing rate. The decreasing rate at temperature between $175^{\circ} \mathrm{C}$ and $200^{\circ} \mathrm{C}$ for Korean paulow- 
Kyung-Rok Won, Tae-Hong Kim, Kyo-Kil Hwang, Song-Ho Chong, Nam-Euy Hong, and Hee-Seop Byeon

Table 2. Bending strength and hardness properties of heat-treated woods

\begin{tabular}{|c|c|c|c|c|c|c|c|c|}
\hline Species & $\begin{array}{c}\text { Heat } \\
\text { treatment } \\
\text { condition }\end{array}$ & & $\begin{array}{c}\mathrm{MOE} \\
\left(\mathrm{kgf} / \mathrm{cm}^{2}\right)\end{array}$ & $\begin{array}{l}\mathrm{R}_{\mathrm{MOE}} \\
(\%)\end{array}$ & $\begin{array}{c}\mathrm{MOR} \\
\left(\mathrm{kgf} / \mathrm{cm}^{2}\right)\end{array}$ & $\begin{array}{c}\mathrm{R}_{\mathrm{MOR}} \\
(\%)\end{array}$ & $\begin{array}{l}\text { Hardness } \\
\left(\mathrm{kgf} / \mathrm{mm}^{2}\right)\end{array}$ & $\begin{array}{l}\mathrm{R}_{\mathrm{HB}} \\
(\%)\end{array}$ \\
\hline \multirow{6}{*}{$\begin{array}{c}\text { Korean } \\
\text { Paulownia }\end{array}$} & Solid & mean & 57,374 & 0 & 433 & 0 & 3.35 & 0 \\
\hline & & S.D & 8,229 & & 14 & & 0.38 & \\
\hline & $175^{\circ} \mathrm{C}$ & mean & 55,010 & -4.12 & 264 & -39.03 & 3.12 & -6.87 \\
\hline & & S.D & 6,608 & & 39 & & 0.72 & \\
\hline & $200^{\circ} \mathrm{C}$ & mean & 51,396 & -10.42 & 145 & -66.51 & 2.26 & -32.54 \\
\hline & & S.D & 7,449 & & 28 & & 0.51 & \\
\hline \multirow{6}{*}{ Pinus densiflora } & Solid & mean & 95,299 & 0 & 876 & 0 & 10.37 & 0 \\
\hline & & S.D & 18,045 & & 61 & & 0.21 & \\
\hline & $175^{\circ} \mathrm{C}$ & mean & 104,778 & +9.95 & 875 & -0.11 & 8.65 & -16.59 \\
\hline & & S.D & 16,162 & & 102 & & 1.81 & \\
\hline & $200^{\circ} \mathrm{C}$ & mean & 113,342 & +18.93 & 660 & -24.66 & 8.58 & -17.26 \\
\hline & & S.D & 17,050 & & 126 & & 1.23 & \\
\hline \multirow{6}{*}{$\begin{array}{l}\text { Lidiodend-ron } \\
\text { tulipifera }\end{array}$} & Solid & mean & 105,984 & 0 & 830 & 0 & 8.54 & 0 \\
\hline & & S.D & 24,611 & & 103 & & 0.46 & \\
\hline & $175^{\circ} \mathrm{C}$ & mean & 109,300 & +3.13 & 583 & -29.76 & 8.35 & -2.22 \\
\hline & & S.D & 21,720 & & 77 & & 1.54 & \\
\hline & $200^{\circ} \mathrm{C}$ & mean & 111,624 & +5.32 & 334 & -59.76 & 6.33 & -25.88 \\
\hline & & S.D & 24,458 & & 160 & & 1.29 & \\
\hline \multirow{6}{*}{ Betula costata } & Solid & mean & 125,461 & 0 & 1236 & 0 & 10.39 & 0 \\
\hline & & S.D & 31,463 & & 104 & & 0.58 & \\
\hline & $175^{\circ} \mathrm{C}$ & mean & 125,007 & -0.36 & 1002 & -18.93 & 12.11 & +16.55 \\
\hline & & S.D & 9,226 & & 162 & & 1.69 & \\
\hline & $200^{\circ} \mathrm{C}$ & mean & 139,683 & +11.34 & 665 & -46.20 & 9.76 & -6.06 \\
\hline & & S.D & 29,467 & & 136 & & 1.69 & \\
\hline
\end{tabular}

Notes; $\mathrm{R}_{\mathrm{MOE}}$ : Ratio of change in MOE after heat treatment,

$\mathrm{R}_{\mathrm{MOR}}$ : Ratio of change in MOR after heat treatment,

$\mathrm{R}_{\mathrm{HB}}$ : Ratio of change in Hardness after heat treatment,

S.D: Standard deviation. RF : Resonance frequency.

nia, Pinus densiflora, Lidiodendron tulipifera and Betula costata showed $-24.78 \%,-35.34 \%$ and $-14.23 \%,-26.52 \%$ and $-26.73 \%,-39.99 \%$ and $-12.53 \%,-31.74 \%$, respectively. It was acted commonly as well not only moisture desorption of wood fiber at the over $100^{\circ} \mathrm{C}$ but also differ- ent composition of each species. Borrega and Kärenlamopi (2008) reported that the weight loss of spruce at the same moisture content increased at the high temperature.

Table 1 shows density of each species after heat treatment. Especially, the highest decreas- 

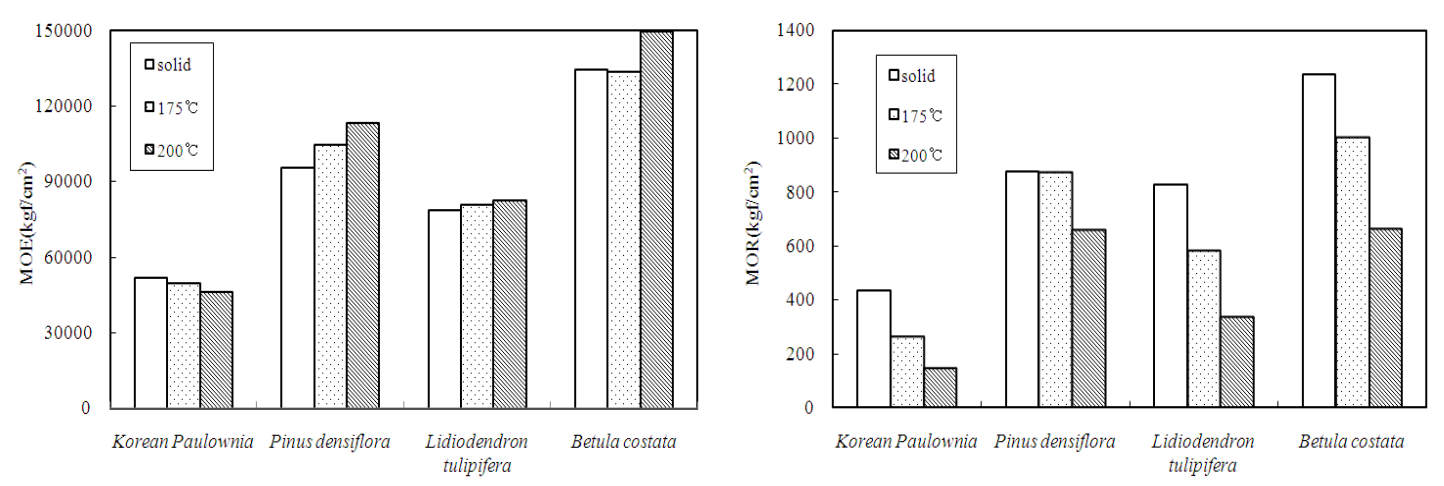

Fig. 1. Bending strength properties of heat-treated woods.

ing rate on the Korean paulownia showed $-25.08 \%$ at the $175^{\circ} \mathrm{C}$ and $-35.12 \%$ at the 200 ${ }^{\circ} \mathrm{C}$. The Lidiodendron tulipifera also showed very high decreasing rate of $-20 \%$ at the $175{ }^{\circ} \mathrm{C}$ and $-32 \%$ at the $200^{\circ} \mathrm{C}$. This result is also due to different component of each species. In addition, the density of heat treatment at the high temperature is lower than heat treatment at the low temperature. The reason why the density of heat treatment at the high temperature is low because hemicellulose was degraded as well at the $200^{\circ} \mathrm{C}$ more than $175^{\circ} \mathrm{C}$. Esteves et al (2007) reported that wood density decrease because of the removal of wood components by heat treatment and moisture desorption.

In studies of the characteristics of pyrolysis for wood has been reported that cellulose, hemicellulose and lignin consist of each component and differ from decomposition temperature (Shafizadeh and McGinnis, 1971; Bridgwater, 2000; Demirbas, 2002). They said that the decomposition temperature was $275 \sim 350^{\circ} \mathrm{C}$ for cellulose, $150 \sim 300^{\circ} \mathrm{C}$ for hemicellulose and $250 \sim 500^{\circ} \mathrm{C}$ for lignin. It shows in the other studies such as the pyrolysis characteristics of wood (Lee, 2003) and hemicellulose was a variety of heterogeneous materials (Manninen, 2002).

\subsection{The Bending Strength of Each Species According to the Heat Treatment}

Table 2 and Fig. 1 shows the averages between the modulus of elasticity (MOE) and the modulus of rupture (MOR) of each species after heat treatment. Before and after heat treatment, Betula costata showed highest bending modulus followed by Lidiodendron tulipifera, Pinus densiflora and Korean paulownia, respectively. Every species increased the bending modulus except Korean paulownia. MOE showed much higher at the $200^{\circ} \mathrm{C}$ than $175^{\circ} \mathrm{C}$. Kocaefe et al (2010) reported that there is a significant change in mechanical properties (MOE, MOR, hardness, etc.) due to heat treatment. Mechanical properies of heat-treated jack pine generally were deteriorated at temperatures higher than $200^{\circ} \mathrm{C}$ compared to those of untreated jack pine.

The density is generally proportional to the modulus of elasticity. However, like in this experiment, decreasing density of the heat-treated wood was caused by decomposition of hemicelluloses, ramification of lignin, and crystallization of cellulose. (Kocaefe et al, 2008). Thereby increasing the MOE. But, further research is required why unlike other species, 
Kyung-Rok Won, Tae-Hong Kim, Kyo-Kil Hwang, Song-Ho Chong, Nam-Euy Hong, and Hee-Seop Byeon

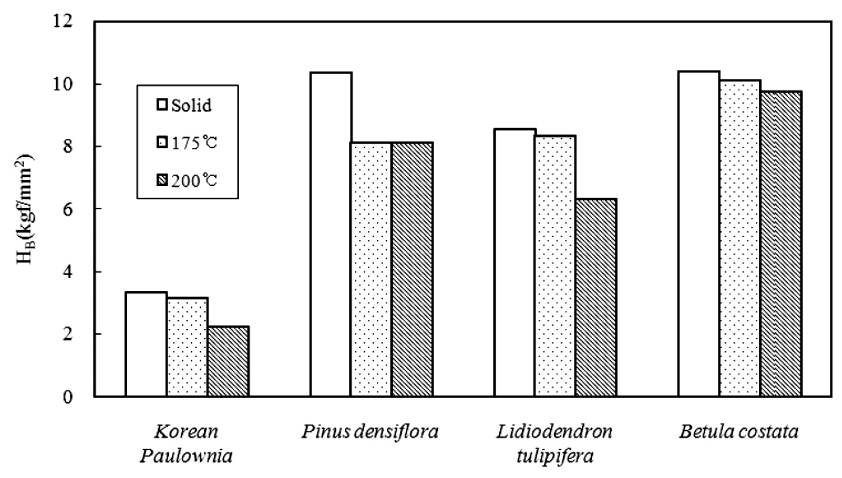

Fig. 2. Hardness property of heat treated woods.

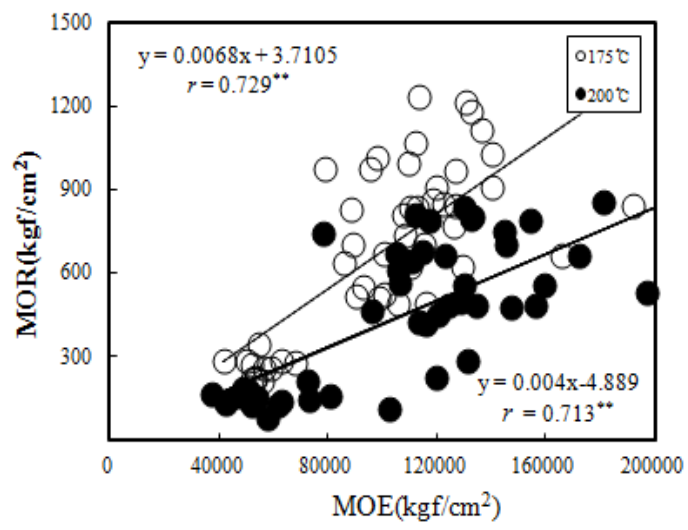

Fig. 3. Relation of bending MOE to MOR of heat treated woods.

MOE of Korean paulownia decreased after heat treatment.

The MOR of heat-treated Betula costata, Lidiodendron tulipifera, Pinus densiflora and Korean paulownia were decreased at temperature of $200^{\circ} \mathrm{C}$ more than those at $175^{\circ} \mathrm{C}$. This deterioration might be explained as due to hemicellulose degradation. Yildiz et al (2006) reported that the heat treatment and control samples were tested for some mechanical properties; compression strength, bending strength, modulus of elasticity in bending, hardness, impact bending strength and tension strength perpendicular to grain. The results indicated that heat treatment samples had lower mechanical properties compared to the control samples. It was seen that hemicelluloses were the wood-cell components most degraded by the heat treatment.

\subsection{The Hardness of Each Species According to the Heat Treatment}

Table 2 and Fig. 2 shows the mean value of each species after heat treatment. Before and after heat treatment, the bending solidity and density was measured lower at the $200^{\circ} \mathrm{C}$ than $175{ }^{\circ} \mathrm{C}$. Betula costata showed highest hardness followed by Lidiodendron tulipifera, Pinus den- 
siflora and Korean paulownia, respectively.

The bending strength and hardness decreased due to the reduction of density after heat treatment. In this study, the heat treatment of specimens treated at the heating rate $10^{\circ} \mathrm{C} / \mathrm{min}$ heating conditions, and maintained for 30 minutes in the maximum temperature of $175^{\circ} \mathrm{C}$ and $200^{\circ} \mathrm{C}$.

Therefore, the maximum temperature of $200^{\circ} \mathrm{C}$ was more active degradation of hemicellulose than $175^{\circ} \mathrm{C}$. Kocaefe et al (2010) reported that there is a significant change in hardness due to heat treatment. The hardness of heat-treated jack pine generally were deteriorated at temperatures higher than $200^{\circ} \mathrm{C}$ compared to those of untreated jack pine.

\subsection{The Bending MOE-Bending MOR, Density-Bending MOE and Density- Hardness Correlation of Heat Treated Wood}

Fig. 3 shows the relation of bending MOE to MOR of heat treated woods. The correlation coefficients for the regression bending $\mathrm{MOE}$ to MOR were 0.729 at the $175^{\circ} \mathrm{C}$ and 0.713 at the $200^{\circ} \mathrm{C}$. Both were significant at the $1 \%$ level, and there were a similar correlations between $175^{\circ} \mathrm{C}$ and $200^{\circ} \mathrm{C}$. Byeon et al (2005) reported that a high correlation coefficient between bending MOE and MOR of finger-jointed wood were similar to this results (significant at the $1 \%$ level). And Nakai (1984) also reported that solid Japanese cedar showed a high correlation coefficient (0.69-0.78) between bending MOE and MOR.

\section{CONCLUSIONS}

Heat treatment tests for four species of woods were performed in order to assess the effects on the bending strength performence and hardness.
The results showed that there was a significant change in mechanical properties such as MOE, MOR and hardness due to heat treatment. The density of heat treatment at the high temperature was lower than heat treatment at the low temperature. The reason why the density of heat treatment at the high temperature is low because hemicellulose was degraded as well at the $200^{\circ} \mathrm{C}$ more than $175^{\circ} \mathrm{C}$. And MOE showed much higher at the $200^{\circ} \mathrm{C}$ than $175^{\circ} \mathrm{C}$. The hardness decreased due to the reduction of density after heat treatment. And, a high correlation and $1 \%$ level of significance were observed in all conditions between bending MOE and bending MOR.

\section{ACKNOLEDGEMENT}

This study was carried out with the support of 'Research center for Ecological Restora- tion in Damaged land (Project No. S211212L0504)' provided by Korea Forest Service.

\section{REFERENCES}

1. Borrega, M. and P. P. Kärenlamopi. 2008. Mechanical behavior of heat-treated spruce (Picea abies) wood at constant moisture content and ambient humidity. Holz als Roh-und Werkstoff 66: $63 \sim 69$.

2. Bridgwater, A. V. 2003. Renewable fuels and chemicals by thermal processing of biomass. Chem. Eng. J 91(2 3): 87 102.

3. Byeon, H. S., H. M. Park, and F. Lam. 2005. Nondestructive evaluation of strength performance for finger-jointed wood using flexural vibration techniques. Forestry Products Journal 55(10): $37 \sim 42$.

4. Byeon, H. S., J. H. Park, K. K. Hwang, H. M. Park, B. S. Park, and S. H. Chong. 2010. Sound absorption property of heat-treated wood at a low temperature and vacuum conditions. Mokchae Konghak 38(2): 123 129.

5. Chang, Y. S., Y. J. Han, C. D. Eom, J. S. Park, 
Kyung-Rok Won, Tae-Hong Kim, Kyo-Kil Hwang, Song-Ho Chong, Nam-Euy Hong, and Hee-Seop Byeon

M. J. Park, I. G, Choi, and H. M. Yeo. 2012. Analysis of factors affecting the hygroscopic performance of thermally treated Pinus koraiensis wood. Mokchae Konghak 40(1): 10 18.

6. Demirbas, A. 2002. Gaseous products from biomass by pyrolysis and gasification: Effects of catalyst on hydrogen yield. Energy conversion and management 43(7): 897 909.

7. Esteves, B., A. V. Marques, I. Domingos, and H. Pereira. 2007. Influence of steam heating on the properties of pine (Pinus Pinaster) and eucalypt (Eucalypus globulus) wood. Wood Sci Technol 41(3): $193 \sim 207$.

8. Garrote, G., H. Dominguez, and J. C. Parajo. 1999. Hydrothermal processing of lignocellulosic materials. European J. of wood and wood products 57(3): $191 \sim 202$.

9. Hakkou M, M. Pétrissens, A. Zoulalian, and P. Gérardin. 2005. Investigation of wood wettability changes during heat treatment on the basis of chemical analysis. Polymer degradation and stability 89(1): $1 \sim 5$.

10. Kamdem D. P., A. Pizzi, and A. Jermammaud. 2002. Durability of heat-treated wood. Holz als Roh-und Werkstoff 60: 1 6.

11. Kim, K. M., J. H. Park, B. S. Park, D. W. Son, J. S. Park, W. S. Kim, B. N. Kim, and S. R. Shim. 2009. Physical and mechanical properties of heat-treated domestic cedar. Mokchae Konghak 37(4): $330 \sim 339$.

12. Kim, K. M., J. H. Park, B. S. Park, D. W. Son, J. S. Park, W. S. Kim, B. N. Kim, and S. R. Shim. 2009. Physical and mechanical properties of heat-treated domestic yellow poplar. Mokchae Konghak 38(1): 17 25.

13. Kocaefe D, S. Poncsak and J. Tang. 2010. Effect of heat treatment on the mechanical properties of North American jack pine: thermogravimetric study. J Mater Sic 45: 681 687 .

14. Kocaefe D, S. Poncsak and Y. Boluk. 2008. Effect of thermal treatment on the chemical composition and mechanical properties of birch and aspen. Bioresources 3(2): 517 537.

15. Lee, S. H., Y. C. Choi, J. G. Lee, and J. H. Kim. 2003. Pyrolysis characteristic study of lumber wastes. Theories and Applications of Chem. Eng $3 \sim 6$.

16. Manninen, A. M., P. Pasanen, and J. K. Holopainen. 2002. Comparing the VOC emissions between air-dried and heat-treated Scots pine wood. Atmospheric Environment 36(11): 1763 1768.

17. Nakai, T. 1984. Full size bending strength of sugi timber. Wood industry 39(11): 42 46.

18. Pavlo, B. and P. Niemz. 2003. Effect of high temperature on the change in color, dimensional stability and mechanical properties of spruce wood. Holzforschung 57(5): 539 546.

19. Poncsak S, D. Kocaefe, M. Bouazara, and A. Pichette. 2006. Effect of high temperature treatment on the mechanical properties of birch. Wood Sci Technol 40(8): 647 663.

20. Shafizadeh, F. and G. D. McGinnis. 1971. Chemical composition and thermal analysis of cottonwood. Carbohydrate Research 16(2): 273 277.

21. Shin, R. H., S. H. Yoon, T. H. Han, and J. H. Kwon. 2009. A study on the development of living products using heat and color conversion treated woods. KFS Journal 20(5): 457 466.

22. Sivonen H, S. L. Maunu, F. Sundholm, S. J Jämsä, and P. Viitaniemi. 2002. Magnetic Resonance Studies of Thermally Modified Wood. Holzforschung 56(6): $648 \sim 654$.

23. Stamm A. J., H. K. Burr and A. A. Kline. 1946. Staybwood-Heat-Stabilized Wood. Ind Eng Chem 38(6): $630 \sim 634$.

24. Tjeerdsma B. F., M. Boonstra, A. Pizzi, H. Tekely and H. Millitz. 1998. Characterisation of thermally modified wood: molecular reasons for wood performance improvement. European J. of wood and wood products 56(3): 149 153.

25. Yildiz, S., E. D. Gezer, and U. C. Yildiz. 2006. Mechanical and chemical behavior of spruce wood modified by heat Building and Environment. 41(12): 1762 1766. 